\title{
DEVELOPMENT OF AN EFFICIENT PROCEDURE FOR THE PRECONCENTRATION OF COPPER(II) AFTER SOLID PHASE EXTRACTION ON MODIFIED SAWDUST
}

\author{
Shahla Elhami ${ }^{*}$ and Marjan Sharifi \\ Department of Chemistry, Khouzestan Science and Research Branch, Islamic Azad University, \\ Ahvaz, Iran
}

(Received November 2, 2013; revised June 23, 2014)

\begin{abstract}
A sensitive and selective preconcentration method has been developed for copper(II) using modified sawdust as an adsorbent. Sawdust was chemically modified with diethylenetriamine. Copper as $\mathrm{CuCl}_{4}{ }^{2-}$ was retained by the adsorbent in the column, eluted by nitric acid and subsequently determined by flame atomic absorption spectrometer. The effect of $\mathrm{pH}$, chloride concentration, volume of the sample and diverse ions on the recovery of the analyte was investigated. A preconcentration factor of 250 was achieved using optimum conditions. The calibration graph was linear in the range $1-150 \mathrm{ng} \mathrm{mL} \mathrm{m}^{-1}$ copper in the initial solution. The detection limit $\left(3 \mathrm{~S}_{\mathrm{b}}\right)$ was $0.2 \mathrm{ng} \mathrm{mL} \mathrm{m}^{-1}$ and the relative standard deviations were 2.7 and $1.2 \%$ for 5 and $50 \mathrm{ng} \mathrm{mL}^{-1}$ respectively $(\mathrm{n}=10)$. It was revealed that after ten cycles of adsorption and desorption, the adsorbent retained its promising adsorption ability. The method was successfully applied to the determination of copper(II) in different water samples. Obtained results showed that the developed method is relatively simple, accurate, sensitive and selective.
\end{abstract}

KEY WORDS: Copper(II), Preconcentration, Modified sawdust

\section{INTRODUCTION}

The determination of metal ions in some natural samples such as waters, soils and biological fluids is a very important part of environmental and public health studies, but direct determination with various instrumental methods is not possible owing to the matrix effect and the low concentration of metal ions in a sample. In trace analysis, therefore, a pre-concentration and/or separation of trace elements from the matrix are frequently necessary to improve the detection limit and selectivity [1]. Various methods have been used for the enrichment and separation of heavy metal ions. Among the various preconcentration techniques, solid phase extraction (SPE) techniques are widely used for the determination of trace metal ions in aqueous samples, because of high preconcentration factor to obtain in short time, low consumption of reagent, simple to operate; and the ability of combination with different detection techniques [2, $3]$. The adsorbents, which have high surface area and adequate sites for adsorption, are preferred in solid-phase extraction of traces of heavy metals. Sawdust is a low cost material that has been used as adsorbent. However, its adsorption capacity is low for some compounds. Chemically modified sawdust has been identified as an innovative and promising class of adsorbent materials.

Copper is an essential element for life in mammals and also for plants and lower forms of organisms. Copper is important not only because it is an essential element, but also because it is toxic at high levels [4]. Different SPE sorbents have been used to the preconcentration of copper such as loaded Amberlite XAD-2 resin [4], polychlorotrifluoroethylene [5], Triton X-100 coated poly vinyl chloride [6], modified activated carbon [1, 7, 8], loaded Amberlite XAD-7 [9], modified alumina [10], octadecyl bonded silica [11], octadecyl-bonded silica memberane disk [12], immobilized salen [13], Dowex optipore V-493 [14], MEFMAT [15], Ambersorb 563 adsorption resin [16] and modified activated carbon [17].

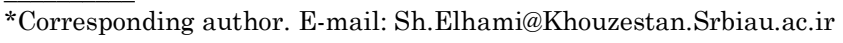


This study reports the sensitive and highly selective preconcentration method for the determination of copper(II). Sawdust was modified by diethylenetriamine (DETA). Modified sawdust has a higher surface area than sawdust and adequate sites for adsorption (amine groups) of copper(II) [18]. Copper as $\mathrm{CuCl}_{4}{ }^{2-}$ is preconcentrated by adsorption on modified sawdust adsorbent, eluted by nitric acid and determined by flame atomic absorption spectrometer (FAAS).

\section{Apparatus and materials}

\section{EXPERIMENTAL}

A PG Instrument PG990 flame atomic absorption spectrometer was used for the determination of copper. All pH measurements were made by a Horiba (model F11) digital $\mathrm{pH}$ meter with a combined glass electrode. An Ultima2C sakht sherkat inductively coupled plasma optical emission spectrometer (Iran) was used. A Tebazma vacuum pump (Iran) was used for pumping the solutions.

All reagents were analytical grade and were used without further purification. A $1000 \mu \mathrm{g}$ $\mathrm{mL}^{-1}$ stock solution of copper(II) was prepared by dissolving $0.3801 \mathrm{~g}$ of copper(II) nitratetrihydrate (Merck, Germany) in $100 \mathrm{~mL}$ water. Working solutions were freshly prepared by appropriate dilution of the stock solution with water. A solution of potassium chloride $(\mathrm{KCl})$ $4.0 \mathrm{~mol} \mathrm{~L}^{-1}$ was prepared by dissolving $29.82 \mathrm{~g}$ of $\mathrm{KCl}$ (Merck, Germany) in water and diluting to $100 \mathrm{~mL}$ in a volumetric flask. A buffer solution of $\mathrm{pH} 4.0$ was prepared by adding $1.0 \mathrm{~mol} \mathrm{~L}^{-1}$ of $\mathrm{NaOH}$ to $1.0 \mathrm{~mol} \mathrm{~L}^{-1}$ acid formic and using a $\mathrm{pH}$ meter to adjust the $\mathrm{pH}$.

\section{Preparation of adsorbent}

The sawdust supplied by a local wood processing factory was washed with distilled water to remove impurity, and then dried overnight at $60{ }^{\circ} \mathrm{C}$. The dried sawdust was sieved to retain the $0.5 \mathrm{~mm}$ fractions for further chemical synthesis. $140 \mathrm{~mL}$ of $\mathrm{HCl}$ concentrated (Merck, Germany) was added to $10 \mathrm{~g}$ of sawdust. After allowing it to stand for $2 \mathrm{~h}, 60 \mathrm{~mL}$ of diethylenetriamine (Merck, Germany) was added too. After allowing it to stand for $30 \mathrm{~min}$, the product was filtered, washed with distilled water, and dried in oven at $40{ }^{\circ} \mathrm{C}$ for $24 \mathrm{~h}$.

\section{General procedure}

A glass tube (70 mm length and $6 \mathrm{~mm}$ i.d.) with a very fine bore was used as a preconcentration column. It was filled with the adsorbent $(0.2 \mathrm{~g})$ then slightly pressing the adsorbent in the column with a flat glass rod. $500 \mathrm{~mL}$ solutions containing $1-150 \mathrm{ng} \mathrm{mL}^{-1}$ of copper(II), $10 \mathrm{~mL}$ of potassium chloride $\left(4 \mathrm{~mol} \mathrm{~L}^{-1}\right)$ to give a final concentration of $0.08 \mathrm{~mol} \mathrm{~L}^{-1} \mathrm{KCl}$ and $50 \mathrm{~mL}$ of formate buffer solution $(\mathrm{pH}=4)$ was passed through the column at a flow rate of $2.5 \mathrm{~mL} \mathrm{~min}{ }^{-1}$. The column packing was then washed with a small volume of water. The metal complex was eluted with $2 \mathrm{~mL}$ of $1.5 \mathrm{~mol} \mathrm{~L}^{-1}$ nitric acid, without using a pump.

The eluents were collected in a $2 \mathrm{~mL}$ volumetric flask, made up to the mark with water. Then, copper(II) was determined by FAAS. The recovery of the metal ions was calculated from the ratio of the concentration found by FAAS to that calculated theoretically.

\section{Pretreatment of water samples}

The tap, river, mineral and wastewater samples were acidified with nitric acid and stored in polyethylene bottles and kept in the refrigerator before use and were filtered prior to the analytical procedure. 


\section{RESULTS AND DISCUSSION}

Diethylenetriamine-sawdust was chosen as an adsorbent for solid phase extraction of $\mathrm{Cu}(\mathrm{II})$. The FT-IR spectra of modified sawdust (it was prepared in accordance with section "preparation of adsorbent") was compared with the FT-IR spectrum of sawdust (sawdust was washed and sieved to retain the $0.5 \mathrm{~mm}$ fractions). The bands I, II, and III (Figure 1) originated from the functional groups $\mathrm{N}-\mathrm{H}, \mathrm{C}=\mathrm{O}$, and $\mathrm{C}-\mathrm{N}$, respectively [19]. Compared with the FT-IR spectrum of sawdust, a more intense and narrow peak depicts at a frequency level around $3422 \mathrm{~cm}^{-1}$, which indicates that a great deal of amino groups have been introduced into the sawdust; also, a disappeared characteristic stretching vibration absorption band of $\mathrm{C}=\mathrm{O}$ (band II) and an increased stretching vibration absorption band of $\mathrm{C}-\mathrm{N}$ (band III) were presented in FTIR spectrum of the modified sawdust. These results confirmed that the diethylentriamine was incorporated into sawdust.

The preliminary experimental observations showed that copper(II), as chloride complex, $\mathrm{CuCl}_{4}{ }^{2-}$ is adsorbed on diethylenetriamine-sawdust by forming an ion pair with ammonium groups then eluted from the column by nitric acid solution, while the sawdust did not have this ability.

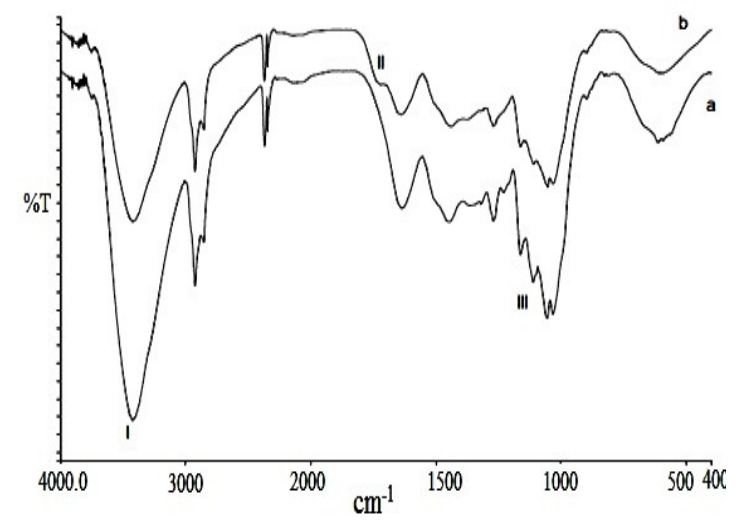

Figure 1. FT-IR spectra of (a) modified sawdust and (b) unmodified sawdust.

\section{Effect of $p H$}

The effect of $\mathrm{pH}$ on the preconcentration of $0.5 \mathrm{mg} \mathrm{L}^{-1}$ of copper(II) was studied in the range of 2-7 by the addition of $\mathrm{HCl}$ or $\mathrm{NaOH}$ and applying the general procedure. Figure 2 shows the influence of $\mathrm{pH}$ on the recovery of the copper(II). As it is observed, maximum recovery is obtained in the range of 3.5-6.0. Therefore, $\mathrm{pH} 4.0$ was chosen for further work. In acidic conditions, the surface of the adsorbent is positively charged due to the high concentration of $\mathrm{H}^{+}$ and amine groups on the adsorbent, so the electrostatic attraction between the adsorbent and the adsorbate $\left(\mathrm{CuCl}_{4}^{2-}\right)$ is enhanced. Lower adsorption of copper complex under alkaline condition, is probably due to the presence of $\mathrm{OH}^{-}$ions on the surface of adsorbents competing with the adsorbate $\left(\mathrm{CuCl}_{4}{ }^{2-}\right)$ for adsorption sites. Different buffer systems with $\mathrm{pH} 4.0$ such as acetate and formate were examined and formate buffer was selected because it did not change the recovery of the solution after preconcentration. Thus, $5 \mathrm{~mL}$ of formate buffer $\mathrm{pH} 4.0$ was added to the sample solutions to maintain the $\mathrm{pH}$ at 4.0 .

\section{Effect of chloride concentration}

The effect of the chloride concentration on the recovery was studied by passing $50 \mathrm{~mL}$ of a solution containing $0.5 \mathrm{mg} \mathrm{L}^{-1}$ of $\mathrm{Cu}(\mathrm{II})$ and $5 \mathrm{~mL}$ of formate buffer through the column. The 
chloride concentration was varied in the range of 0.00 to $0.16 \mathrm{~mol} \mathrm{~L}^{-1}$ and the recovery was determined by FAAS after preconcentration following the general procedure. The results are shown in Figure 3. It was found that the recovery of $\mathrm{Cu}$ increased up to a chloride concentration of $0.06 \mathrm{~mol} \mathrm{~L}^{-1}$ and reached a plateau above that. Therefore, a chloride concentration of 0.08 mol L ${ }^{-1}$ in the final solution was selected for the further experiments.

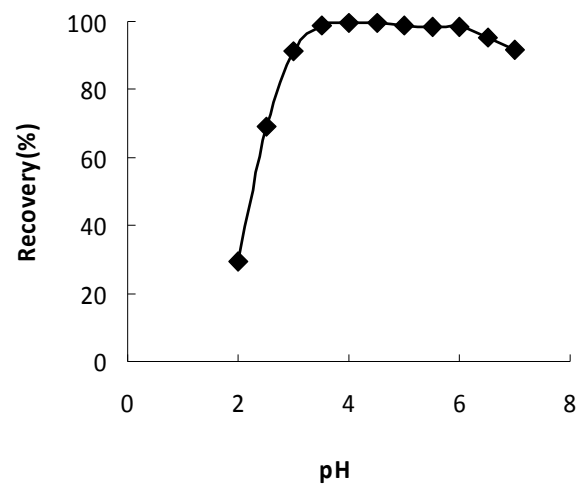

Figure 2. The effect of $\mathrm{pH}$ on the recovery of $\mathrm{Cu}$ (II) (Concentration of $\mathrm{Cu}$ (II) $=500 \mathrm{ng} \mathrm{mL}^{-1}$, volume of the sample $=50 \mathrm{~mL}$, chloride concentration $=1.0 \mathrm{~mol} \mathrm{~L}^{-1}$ ).

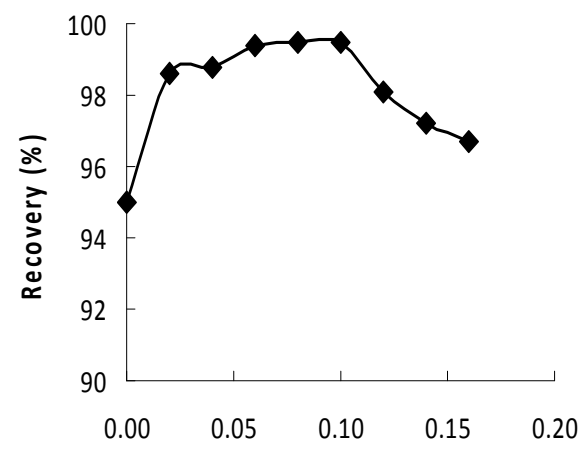

$\mathrm{KCl}$ concentration (mol/L)

Figure 3. The effect of chloride concentration on the recovery of $\mathrm{Cu}$ (II) (concentration of $\mathrm{Cu}$ (II) $=500 \mathrm{ng} \mathrm{mL}^{-1}$, volume of the sample $=50 \mathrm{~mL}, \mathrm{pH}=4.0$ ).

Choice of eluent

A satisfactory eluent should quantitatively elute the sorbed analytes with a small volume, which is needed for a high enrichment factor. For this reason, various solutions such as nitric acid, hydrochloric acid and sulfuric acid were used to identify the best eluent for the sorbed metal on the diethylenetriamine-sawdust sorbent. Among the eluents studied, nitric acid provided higher recoveries compared to sulfuric acid and hydrochloric acid. Therefore, the effect of nitric acid concentration was studied. The results indicated that the highest recoveries were obtained when nitric acid concentration was above $1 \mathrm{M}$. Thus, $1.5 \mathrm{M}$ of nitric acid was chosen as the eluent. The effect of volume of nitric acid was also investigated and quantitative recoveries were obtained for $2-5 \mathrm{~mL}$ of the eluent. The optimum eluent volume was specified as $2 \mathrm{~mL}$ for the subsequent studies. 
Effect of the amounts of diethylenetriamine loaded on sawdust

The quantity of diethylenetriamine loaded on the sorbent is an important chemical variable affecting the preconcentration of the examined analytes. Therefore, the effect of the amount of diethylenetriamine loaded on sawdust $(1.0 \mathrm{~g})$ was investigated in the range of $1.0-10.0 \mathrm{~mL}$ at optimum conditions. The results showed that the recovery was constant above $6.0 \mathrm{~mL}$. When the amount of diethylenetriamine was less than $6.0 \mathrm{~mL}$, there were not enough sites. Therefore, $6.0 \mathrm{~mL}$ of diethylenetriamine loaded on $1.0 \mathrm{~g}$ of sawdust $\left(6.0 \mathrm{~mL} \mathrm{~g}^{-1}\right)$ was chosen for further work.

\section{Effect of the adsorbent mass}

In order to test the effect of the adsorbent mass on quantitative retention of $\mathrm{CuCl}_{4}{ }^{2-}$ complex, different amounts of diethylenetriamine-sawdust adsorbent $(0.05-0.40 \mathrm{~g})$ were chosen and the experimental method was applied. Quantitative adsorption was not obtained when the mass of adsorbent was smaller than $0.15 \mathrm{~g}$. Thus $0.20 \mathrm{~g}$ of diethylenetriamine-sawdust was selected for further studies (Figure 4).

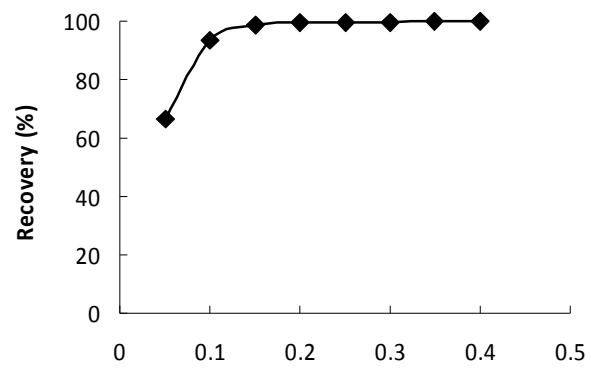

Adsorbent masss (g)

Figure 4. The effect of adsorbent mass on the recovery of $\mathrm{Cu}(\mathrm{II})$, (concentration of $\mathrm{Cu}(\mathrm{II})=500$ $\mathrm{ng} \mathrm{mL}$, volume of sample $=50 \mathrm{~mL}$, chloride concentration $=1.0 \mathrm{~mol} \mathrm{~L}^{-1}$ ).

\section{Effect of sample flow rate}

The effect of sample flow rate was studied by passing identical samples with different flow rates ranging from 0.625 to $10.0 \mathrm{~mL} \mathrm{~min}^{-1}$ (Figure 5). The optimized flow rate was selected as $2.5 \mathrm{~mL}$ $\min ^{-1}$.

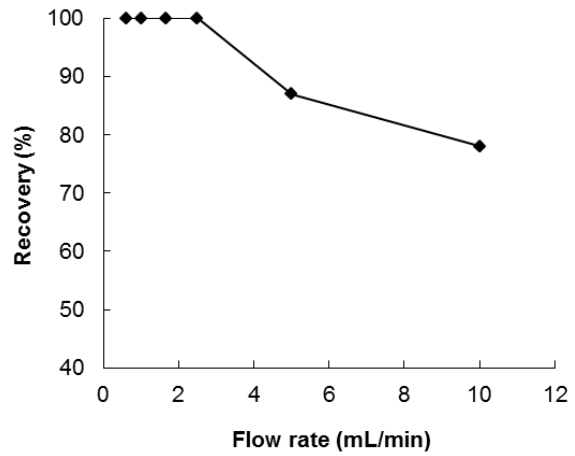

Figure 5. The effect of sample flow rate on the recovery of $\mathrm{Cu}$ (II) (concentration of $\mathrm{Cu}(\mathrm{II})=500$ $\mathrm{ng} \mathrm{mL} \mathrm{m}^{-1}$, volume of sample $=50 \mathrm{~mL}, \mathrm{pH}=4.0$, chloride concentration $=1.0 \mathrm{~mol} \mathrm{~L}^{-1}$ ).

Bull. Chem. Soc. Ethiop. 2014, 28(3) 
Effect of sample volume

For the preconcentration of trace elements, it is desirable to consider a variety of preconcentration factors. In order to achieve a high preconcentration factor, the breakthrough volume of sample solution should be established. The effect of sample volume on the adsorption of $\mathrm{CuCl}_{4}{ }^{2-}$ complex was studied in the range of 50-500 mL. Each solution contained the same amount of $\mathrm{Cu}^{2+}$ and the adsorption and desorption processes were performed under the optimum conditions. The results showed that the $\mathrm{CuCl}_{4}{ }^{2-}$ present in various volumes of solution was completely and quantitatively adsorbed on diethylenetriamine-sawdust. The adsorption decreased at higher volumes than $500 \mathrm{~mL}$. Therefore, to determine trace quantities of $\mathrm{Cu}^{2+}$ in samples, a sample volume up to $500 \mathrm{~mL}$ could be selected in order to increase the preconcentration factor to 250 .

\section{Regeneration of column}

Regeneration studies of the adsorbent are of great importance because these are helpful to explore the possibility of recycling the adsorbents and the recovery of sorbed materials from the adsorbent. For regeneration study in this research, a glass tube ( $70 \mathrm{~mm}$ length and $6 \mathrm{~mm}$ i.d.) with a very fine bore was used as a regeneration column. It was filled with $0.2 \mathrm{~g}$ adsorbent after slightly pressing the adsorbent in the column with a flat glass rod. $50 \mathrm{~mL}$ solutions containing $200 \mathrm{ng} \mathrm{mL}^{-1}$ of copper(II) (in optimum condition) was passed through the column. The column was eluted with $2 \mathrm{~mL}$ of $1.5 \mathrm{~mol} \mathrm{~L}^{-1} \mathrm{HNO}_{3}$. Then the column was washed with $100 \mathrm{~mL}$ of water. This cycle was repeated 10 times, in all cycles the recovery was about $98 \%$. These results show that the adsorbent has a high capacity for regeneration.

\section{Analytical performance}

A linear calibration graph was drawn for the determination of copper(II) under the proposed experimental conditions. The data yielded a good linearity in the range of $1-150 \mathrm{ng} \mathrm{mL}^{-1}$ copper(II). The equation of the line was $\mathrm{A}=0.0098 \mathrm{C}+0.0022$ with a regression coefficient of $r=0.9977(n=10)$. The limit of detection (LOD) defined as the concentration of the analyte giving signals equivalent to three standard deviations of the blank $\left(3 \mathrm{~S}_{\mathrm{b}}\right)$ was $0.2 \mathrm{ng} \mathrm{mL}^{-1}$ and the relative standard deviations (RSD) for ten replicate measurements of 5 and $50 \mathrm{ng} \mathrm{mL} \mathrm{m}^{-1}$ of copper(II) were 2.7 and $1.2 \%$, respectively.

Table 1. Comparison of present method with previously reported.

\begin{tabular}{|l|c|c|c|c|c|}
\hline Adsorbent & PF & RSD $(\%)$ & LOD $(\mathrm{ng} / \mathrm{mL})$ & AM $(\mathrm{g})$ & Ref. \\
\hline Modified activated carbon & 135 & 2.2 & 2.4 & 0.6 & {$[1]$} \\
Amberlite XAD-2 & 160 & 1.8 & 0.1 & 0.2 & {$[4]$} \\
Modified activated carbon & 330 & 2 & 0.5 & 0.5 & {$[8]$} \\
Amberlite XAD-7 & - & 9 & 0.1 & 0.06 & {$[9]$} \\
Memberane disk & 200 & 2.5 & 0.3 & - & {$[12]$} \\
Immobilized salen & 100 & 4.5 & 0.3 & - & {$[13]$} \\
Dowex optipore V-493 & 37 & 9 & 1.1 & - & {$[14]$} \\
MEFMAT & 50 & 3.5 & 1.5 & - & {$[15]$} \\
Modified sawdust & 250 & 2.7 & 0.2 & 0.2 & This work \\
\hline
\end{tabular}

PF: Preconcentration factor, AM: adsorbent mass.

In Table 1, the figures of merit of the present and other selected solid phase extraction preconcentration FAAS methods are summarized for comparative purposes. The proposed method shows very good sensitivity and precision and has some good advantages over other preconcentration methods reported in the literature. Only the method which uses modified 
activated carbon [8] shows better preconcentration factor; but LOD and adsorbent mass were worse. The methods which use Amberlite XAD-2 [4] and Amberlite XAD-7 [9] have a lower detection limit, but they have preconcentration factor [4] or RSD [9] worse.

\section{Interference studies}

In order to evaluate the selectivity of the method, the effects of different ions on the solid phase extraction and determination of copper were investigated. A constant concentration of copper(II) (20 ng mL ${ }^{-1}$ ) was taken with different concentrations of ions and the general procedure was followed. Any deviation of $\pm 5 \%$ or more from the absorbance value of the standard solution was considered as interference. Results given in Table 2 indicate that the proposed method is relatively selective for the determination of copper(II).

Table 2. Effect of the interference of diverse ions on the recovery of copper(II).

\begin{tabular}{|l|c|}
\hline Diverse ion & $\begin{array}{c}\text { Tolerance ratio (foreign } \\
\text { species conc./Cu }\end{array}$ \\
\hline $\mathrm{Na}^{+}, \mathrm{CH}_{3} \mathrm{COO}^{-}, \mathrm{HPO}_{4}{ }^{-}, \mathrm{K}^{+}, \mathrm{Mg}^{2+}, \mathrm{Ca}^{2+}, \mathrm{Cr}_{2} \mathrm{O}_{7}{ }^{2-}, \mathrm{Ba}^{2+}, \mathrm{CrO}_{4}^{-}{ }^{-} \mathrm{Ni}^{2+}, \mathrm{Fe}^{2+}$, & 1000 \\
$\mathrm{Fe}^{3+}, \mathrm{Sn}^{2+}, \mathrm{Co}^{2+}$ & 800 \\
$\mathrm{~Pb}^{2+}, \mathrm{NH}_{4}^{+}$ & 600 \\
$\mathrm{NO}_{3}{ }^{2}, \mathrm{Ag}^{+}, \mathrm{Cd}^{2+}, \mathrm{CO}_{3}{ }^{2-}, \mathrm{Cl}^{-}$ & 400 \\
$\mathrm{Zn}^{2+}, \mathrm{Br}^{-}$ & 100 \\
$\mathrm{Hg}^{2+}, \mathrm{Bi}^{3+}$ & \\
\hline
\end{tabular}

\section{Application}

The proposed preconcentration procedure was applied to the determination of trace copper in water samples. Different amounts of copper(II) were spiked to the tap, river, mineral and wastewater samples and the recovery was calculated related to spiked. The results are given in Table 3. Good agreement was obtained between the added and found analyte content using the recommended procedure. The recovery value for the analyte ions was in the range of $91-98 \%$. As can be seen, the proposed method gave good recoveries.

Table 3. Determination of copper in real samples.

\begin{tabular}{|c|c|c|c|c|c|}
\hline \multirow[t]{2}{*}{ Sample } & \multirow{2}{*}{$\begin{array}{l}\mathrm{Cu}(\mathrm{II}) \text { Added } \\
\left(\mathrm{ng} \mathrm{mL}^{-1}\right)\end{array}$} & \multicolumn{2}{|c|}{ Proposed method } & \multicolumn{2}{|c|}{ ICP method } \\
\hline & & $\begin{array}{l}\text { Found }^{\mathrm{a}} \\
\left(\mathrm{ng} \mathrm{mL}^{-1}\right)\end{array}$ & $\begin{array}{c}\text { Recovery } \\
(\%)\end{array}$ & $\begin{array}{l}\text { Found } \\
\left(\mathrm{ng} \mathrm{mL}^{-1}\right)\end{array}$ & $\begin{array}{c}\text { Recovery } \\
(\%)\end{array}$ \\
\hline \multirow{3}{*}{ Tap water } & 0 & $4.5 \pm 0.2$ & - & & \\
\hline & 50 & $50.0 \pm 1.1$ & 91.0 & & \\
\hline & 100 & $96.4 \pm 1.9$ & 92.0 & & \\
\hline \multirow[t]{3}{*}{ Mineral water } & 0 & $1.7 \pm 0.3$ & - & & \\
\hline & 50 & $49.7 \pm 0.9$ & 96.0 & & \\
\hline & 100 & $98.8 \pm 1.4$ & 97.1 & & \\
\hline \multirow{3}{*}{ River water } & 0 & $4.1 \pm 0.1$ & - & & \\
\hline & 50 & $51.2 \pm 1.1$ & 94.2 & & \\
\hline & 100 & $98.9 \pm 1.5$ & 94.8 & & \\
\hline \multirow[t]{3}{*}{ Waste water } & 0 & $4.3 \pm 0.2$ & - & & \\
\hline & 50 & $52.6 \pm 1.0$ & 96.6 & & \\
\hline & 100 & $102 \pm 2.1$ & 97.7 & & \\
\hline \multirow[t]{2}{*}{ Synthetic Water } & 0 & $\mathrm{ND}^{\mathrm{b}}$ & - & ND & - \\
\hline & 50 & $48.5 \pm 0.9$ & 97.0 & 48.0 & 96.0 \\
\hline
\end{tabular}

${ }^{\mathrm{a}} x \pm \mathrm{ts} / \sqrt{ } n$ at $95 \%$ confidence $(\mathrm{n}=5),{ }^{\mathrm{b}}$ Not detected. 
In order to estimate the accuracy of the procedure, one synthetic sample was also analyzed by both this method and ICP method. The solution contained $\mathrm{Cu}^{2+}\left(50 \mathrm{ng} \mathrm{mL}^{-1}\right), \mathrm{Na}^{+}, \mathrm{K}^{+}, \mathrm{Ca}^{2+}$, $\mathrm{Ni}^{2+}, \mathrm{Zn}^{2+}, \mathrm{Co}^{2+}, \mathrm{Fe}^{3+}, \mathrm{Cd}^{2+}, \mathrm{Mg}^{2+}, \mathrm{Sn}^{2+} 500 \mathrm{ng} \mathrm{mL}^{-1}$ of each cation. The values obtained for $\mathrm{Cu}^{2+}$ by using ICP $\left(48.0 \mathrm{ng} \mathrm{mL}^{-1}\right)$ and this method $\left(48.5 \mathrm{ng} \mathrm{mL}^{-1}\right)$ show that there is a good agreement between the results of the two methods and that there was no significant difference between them as performing a t-test at $95 \%$ confidence limit reveals.

\section{CONCLUSIONS}

A pre-concentration of $\mathrm{Cu}$ from aqueous solution on modified sawdust with DETA column was successfully developed. The FT-IR spectra showed that a chemical modification was successfully occurred. The method is simple, fast and economical. The determination procedure was characterized by good reproducibility and accuracy. The presented preconcentration procedure shows high tolerance to interference from matrix ions. Preconcentration factor is higher (250) than some other methods $[1,4,12-15]$. The column is also easily reproducible without the need of pre-conditioning or activation steps. The proposed procedure was applied for copper determination in various water samples. A high enrichment factor (250), simplicity and high regeneration of adsorbent were the main advantages in this analytical method.

\section{ACKNOWLEDGMENTS}

The financial support of this work by Khouzestan Science and Research Branch, Islamic Azad University is greatly acknowledged.

\section{REFERENCES}

1. Ahmadi, F.; Khodabakhash Niknam, A.; Jafarpour, J. Arab. J. Sci. Eng. 2009, 34, 21.

2. Chalapathi, K.; Ramesh Babu, L.; Ravi, V.; Maddaiah, G.P. Res. J. Pharm. Biol. Chem. Sci. 2010, $1,515$.

3. Ghaedi, M.; Niknam, K.; Niknam, E.; Mortazavi, K.; Taher, K.; Soylak, M. J. Chin. Chem. Soc. 2010, 57, 275.

4. Taher, M.A.; Mohammadi, S.Z.; Mohadesi, A.R. Turk. J. Chem. 2005, 29, 17.

5. Anthemidis, A.N.; Ioannou, K.I. Anal. Chim. Acta 2006, 575, 126.

6. Ghaedi, M.; Niknam, E. Bull. Chem. Soc. Ethiop. 2010, 24, 11.

7. Chalapathi, K.; Maddaiah, G.P. J. Chem. Pharm. Res. 2010, 2, 27.

8. Ghaedi, M.; Ahmadi, F.; Soylak, M. J. Hazard. Mater. 2007, 147, 226.

9. Yamen, M.; Ince, M.; Kaplan, O. Water Environ. Res. 2008, 80, 2104.

10. Hossini, M.; Dalali, N.; Karimi, A.; Dastanra, K. Turk. J. Chem. 2010, 34, 805.

11. Hossini, M.; Dalali, N. Indian J. Chem. Technol. 2012, 19, 337.

12. Dalali, N.; Farhangi, L.; Hosseini, M. Indian J. Chem. Technol. 2011, 18, 183.

13. Dadfarnia, S.; Shabani, A.M.; Tamaddon, F. Anal. Chim. Acta 2005, 539, 69.

14. Tuzen, M.; Melek, E.; Soylak, M. J. Hazard. Mater. 2008,159, 335.

15. Duran, C.; Ozdes, D.; Sahin, D.; Bulut, V.N.; Gundogdu, A.; Soylak, M. Microchem. J. 2011, 98, 317.

16. Saracoglu, S.; Soylak, M.; Elci, L. Chem. Anal. (Warsaw) 2003, 48, 77.

17. Ghaedi, M.; Ahmadi, F.; Baezat, M.R.; Safari, J. Bull. Chem. Soc. Ethiop. 2008, 22, 331.

18. Elhami, Sh.; Abrishamkar, M.; Shafamehr, A. Caspian J. Appl. Sci. Res. 2013, 2, 24.

19. Gong, R.; Ni, Sh.; Zhao, J.; Li, N. Wood Sci. Tech. 2009, 43,183. 